\title{
Characterization of Cones and Seeds of Damar (Agathis labillardieri) from Plantation in Klasaman, Sorong
}

\author{
Jeffry Cornelis Angkotta, ${ }^{1, *}$, Julius Dwi Nugroho ${ }^{2 *}$, Nurhaida Iriany Sinaga ${ }^{2}$ \\ ${ }^{1}$ Study Program of Forestry, Graduate Programme, University of Papua. Jl. Gunung Salju, Amban, Manokwari 98314, Papua \\ Barat, Indonesia \\ ${ }^{2}$ Faculty of Forestry, University of Papua. Jl. Gunung Salju Amban Manokwari 98314, Papua Barat, Indonesia \\ ${ }^{*}$ Corresponding Author. E-mail address: j.nugroho@unipa.ac.id
}

\section{ARTICLE HISTORY:}

Received: 10 July 2021

Peer review completed: 2 December 2021 Received in revised form: 15 January 2022 Accepted: 24 January 2022

\section{KEYWORDS:}

Agathis labillardieri Filled seed

Germination

Natural regeneration

Recalcitrant seed

(C) 2022 The Author(s). Published by Department of Forestry, Faculty of Agriculture, University of Lampung in collaboration with Indonesia Network for Agroforestry Education (INAFE).

This is an open access article under the CC BY-NC license:

https://creativecommons.org/licenses/by$\mathrm{nc} / 4.0 /$

\begin{abstract}
Damar (Agathis labillardieri) is endemic species to New Guinea, occurring naturally in Papua and West Papua Province, Indonesia. The species is economically valuable due to its resin and wood. This research aimed to study the cones and seeds characteristics of $A$. labillardieri collected from Sorong Nature Park at Klasaman, Sorong, Papua Barat. The characteristics observed included cone size and weight, number of scales, empty and filled seed, and seed moisture content. The germination test was also performed. Although the stands could produce cones, not all scales contained seeds, and not all seeds were filled seeds. On average, 53 filled seeds per cone or only $50.3 \pm 5.7 \%$ of the total seeds found as filled seeds. The seed was characterized as a recalcitrant seed with high moisture content and rapid germination. On average, the seed moisture content was $38.9 \%$, with an average germination time of four days. The combined factors that may contribute to the low natural regeneration of $A$. labillardieri are low filled seeds, seed sensitivity to desiccation, and high mortality in newly emerging seedlings during recruitment. Therefore, facilitating the forest floor for immediate germination of recalcitrant seeds as in A. labillardieri is suggested.
\end{abstract}

\section{Introduction}

Damar (Agathis labillardieri) is a tree species in the family Araucariaceae. The tree is monopodial, has a large size with a moderate growth rate (Kartikasari et al. 2012; Siburian et al. 2020), and can live for hundreds of years (Rachman 2007; Saa et al. 2009). A. labillardieri is one of the selected species developed in industrial plantation forests in Papua and West Papua due to its economic value. The species is a resin producer known as copal that is widely used in the industry of paints, varnishes, waterproofing, methylates, textile coatings, and drying liquids (Farjon 2013). Copal of A. labillardieri contains 1-pinene of $31.8 \%$ and limonen of $60.3 \%$ (Resmeiliana et al. 2014). It is also regarded as a valuable wood producer. The wood has bright color and is suitable for pulp and paper, plywoods, and furniture (Herliyana 2012).

Agathis labillardieri is a conifer species endemic to New Guinea that spread naturally in Papua and West Papua Provinces of Indonesia to Northwestern Papua New Guinea in the Sepik basin (Farjon 2013). This species can be found in Papua and West Papua provinces, such as in Yapen, Waigeo Island, and South Sorong (Kartikasari et al. 2012). A. labillardieri grows naturally 
mixed with other species and distributed from low land forest to the altitude of 800 masl. Kartikasari et al. (2012) stated that this species could be found naturally in lowland to lower montane forests with an altitude of 200-1,700 masl. According to the International Union for Conservation of Nature (IUCN), this species has been included in the list species category of near threatened (NT) (Farjon 2013).

Some reports stated that the regeneration $A$. labillardieri does not occur well. For example, Olim and Nugroho (2021) found a small number of seedlings due to regeneration under the $A$. labillardieri plantation stands in University of Papua Educational Forest in Anggori, Manokwari. Likewise, Saa et al. (2009) found low regeneration in the plantation forest of Bariat, South Sorong. Other plantations of $A$. labillardieri can also be found in the Sorong Nature Park at Klasaman, Sorong. All the sites are not a natural habitat of $A$. labillardieri. Regeneration characteristics like this often resulted in seedling stocks scarcity. Therefore, understanding the constraints of $A$. labillardieri regeneration is urgently needed for supporting sustainable plantation management when the development of plantations is set up outside its natural habitat. The objective of the study is to describe the characteristics of cones and seeds of $A$. labillardieri, specifically the reproductive indicators such as the number of filled seeds per cone and germination capability of the seeds. Those indicators were used for discussing their attribute to the low natural regeneration of the species in some plantations.

\section{Materials and Methods}

\subsection{Plant Materials}

The cones of $A$. labillardieri were obtained from plantation stands of Sorong Nature Park in Klasaman Sorong, West Papua, located between $0^{\circ} 55^{\prime}$ 03,53” E and $131^{\circ} 20^{\prime} 18.99$ ' S. The site has a humid tropical climate with annual precipitation of $2,657 \mathrm{~mm}$ and a mean daily temperature of around $28^{\circ} \mathrm{C}$. The soils of the site belong to brown-grey podsolic (ultisols) and alluvial soils (entisols) with an elevation of approximately 29 masl at the trees where the cones were collected (Fig. 1). Based on the chemical characteristics, the soil is categorized as low to medium soil fertility, with a total $\mathrm{C}$ of $0.16-0.68 \%, \mathrm{~N}$ of $0.10 \%$, and $\mathrm{P}$ of $0.19-0.48 \mathrm{ppm}$. The topography of the site is flat to mild topography. The age of the plantation in the site varied from 57 to 63 years old (BBKSDA Papua Barat 2014). Observation of cone and seed characteristics was conducted at Silviculture Laboratory of Forestry Faculty, University of Papua, Manokwari.

The cones were harvested from three trees, and some fallen cones were collected from the floor of the plantation. However, only freshly harvested fruits that had attained physiologically ripe, i.e., having dark green color, were used to identify empty or filled seed and seed germination (Rachman 2007). The cones collected from the field were wrapped using aluminum foil, then put in plastic zippers, given moisturizer in the form of wet tissue to avoid desiccation. The cones were immediately transported to the laboratory for observations and germination tests.

\subsection{Characterization of Fruits and Seeds}

The characteristics of cones and seeds were observed visually. Dimension of the fruit (length and diameter) was measured using a veneer caliper, and the weight of the fruit was measured using a digital balance. While the number of scales per fruit, scales containing seed per fruit were counted manually. The collected seeds were then sorted into the following categories: empty seeds 
and filled seeds. The moisture contents of the seeds were identified using the method of desiccation (Shibata et al. 2013). The formula to calculate the moisture content of the seed is as follows:

$$
M C=\frac{W_{1}-W_{0}}{W_{0}} \times 100 \%
$$

where $M C$ is seed moisture content (\%), $W_{l}$ is initial seed weight $(\mathrm{g})$, and $W_{0}$ is the over weight of seed sample (g).

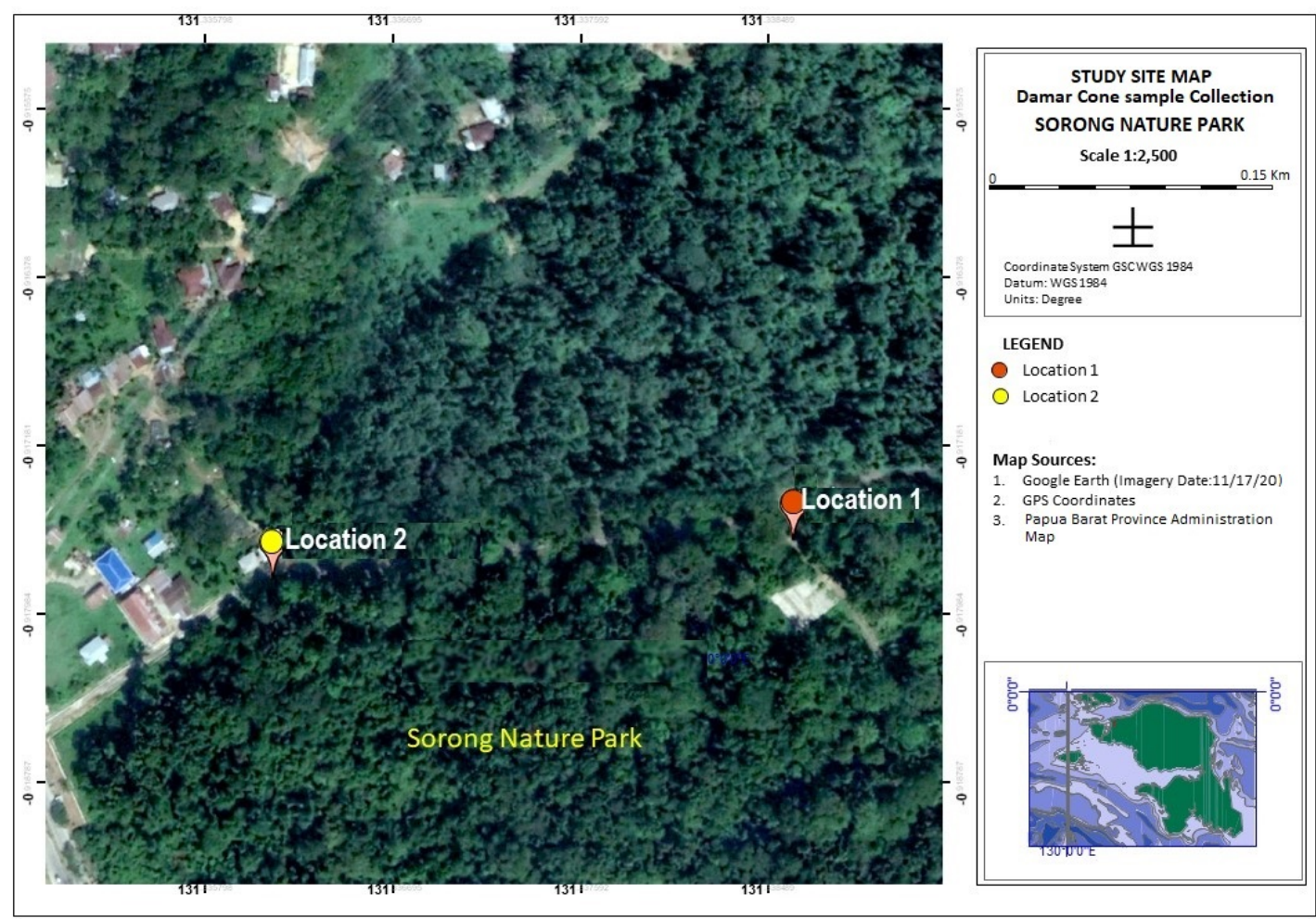

Fig. 1. The location of Agathis labillardieri plantation of the Sorong Nature Park. Location 1 (red dot) and location 2 (yellow dot) are the location of the stands where the cone samples were collected.

The seed germination test was also performed to identify the characteristics of the seed germination capability. Twenty filled seeds taken from physiologically ripe fruit were selected for the test. The test was conducted using the wet filter paper method in a Petri dish. The variables of the germination test are as follows:

1. Germination percentage (GP) is the number of seeds (in percent) capable of germinating until the end of the test (12 days after sowing) (Caliskan 2014; Wulandari et al. 2015).

2. Mean germination time (MGT) is measured based on the average days required to germinate and calculated as follows:

$$
M G T=\frac{\sum\left(t_{i} n_{i}\right)}{\sum n_{i}}
$$

where $t$ is the day required to germinate, calculated from the time of seeding (0) and $n=$ the number of germinated seeds at the end of the observation (14 days after seeding) (Wulandari et al. 2015; Gonzales-Rivas et al. 2009).

3. Mean daily germination (MDG) is measured based on the equation:

$$
M D G=N / t
$$

where $\mathrm{N}$ is the total number of germinated seeds at the end of observation and $\mathrm{t}$ is the time of observation days (12 days) (Wulandari et al. 2015). 
4. Peak value (PV) is the point at which the percentage of seed germination begins slowdowns divided by the day needed to reach it (Caliskan 2014; Wulandari et al. 2015).

5. Germination value (GV) was calculated using equation 4 (Wani and Singh 2016).

$$
G V=P V x M G T
$$

\subsection{Data Analysis}

Data analysis was performed using descriptive statistics and standard deviations. The results of data analysis are presented in figures, graphs, and tables. Statistical procedures were performed using Minitab Released 14 Software.

\section{Results and Discussion}

\subsection{Results}

Agathis labillardieri cone consists of the scales arranged on the cone axis. The cone generally has an oval shape. The young cone has a rough surface of scales with light green color, while the ripe cone has slippery and more delicate scales with dark green color (Fig. 2A and 2B). The seeds are attached to the inner cone scales (Fig. 2C) with various seed wings (Fig. 2E). When the cone ripes or desiccates, the scales detach, and at the same time, the seeds will be released.

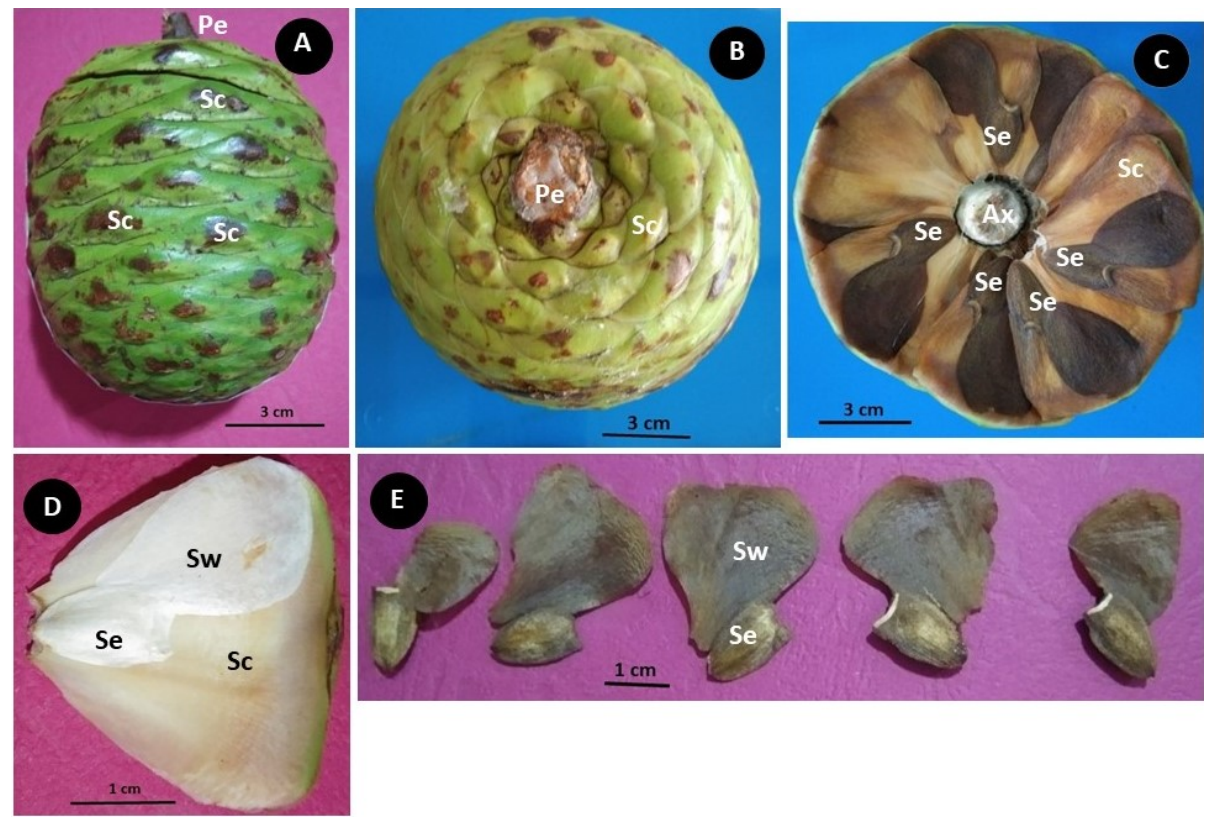

Fig. 2. The cone and seed of Agathis labillardieri and its parts- $\mathrm{Pe}=$ peduncle, $\mathrm{Sc}=$ cone scale, $\mathrm{Se}=$ seed, $\mathrm{Sw}=$ seed wing, (A) Side view of the cone, (B) Basal view of the cone, (C) A part of a broken cone with some cone scales and seed attached, (D) Seed attached on cone scale, and (E) Seed wing variation.

The cone of $A$. labillardieri weighed $436.6 \pm 115.4 \mathrm{~g}$ with a diameter and length of $88.6 \pm$ $9.6 \mathrm{~cm}$ and $94.1 \pm 13.3 \mathrm{~cm}$, respectively. The number of cone scales reached $133 \pm 21$ scales. However, not all cone scales contained seeds. Of the total cone scales, about $80.0 \pm 7.9 \%$ contained seeds. However, of all the seeds formed, only about $50.3 \pm 5.7 \%$ had filled seeds, and the rest were empty seeds. The moisture content of the seeds was about $38.9 \pm 6.3 \%$ (Table 1). 
Table 1. Characteristics of cones and seeds Agathis labillardieri with the average values and standard deviations of each character

\begin{tabular}{lccccccc}
\hline $\begin{array}{c}\text { Statistical } \\
\text { values }\end{array}$ & $\begin{array}{c}\text { Cone } \\
\text { weight } \\
(\mathbf{g})\end{array}$ & $\begin{array}{c}\text { Cone } \\
\text { diameter } \\
(\mathbf{c m})\end{array}$ & $\begin{array}{c}\text { Cone } \\
\text { length } \\
(\mathbf{c m})\end{array}$ & $\begin{array}{c}\text { Number of } \\
\text { cone scales } \\
(\mathbf{N})\end{array}$ & $\begin{array}{c}\text { Scales } \\
\text { contained } \\
\text { seeds (\%) }\end{array}$ & $\begin{array}{c}\text { Filled } \\
\text { seeds (\%) }\end{array}$ & $\begin{array}{c}\text { MC } \\
(\%)\end{array}$ \\
\hline Average & 436.6 & 88.6 & 94.1 & 133.0 & 80.0 & 50.3 & 38.9 \\
Stdev & 115.4 & 9.6 & 13.3 & 21.0 & 7.9 & 5.7 & 6.3 \\
\hline
\end{tabular}

Agathis labillardieri seeds, on average, took 4 days to germinate (MGT), with mean daily germination (MDG) was 7.5 seeds per day. The germination peak occurred on the 6 (DAS) when $70 \%$ of the seeds had already germinated. After that day, the germination went slow down. The peak value (PV) was 11.6. At the end of the germination test, the percent seed germination (PG) reached 90\%, and the germination value (GV) was 87 (Fig. 3 and Table 3).

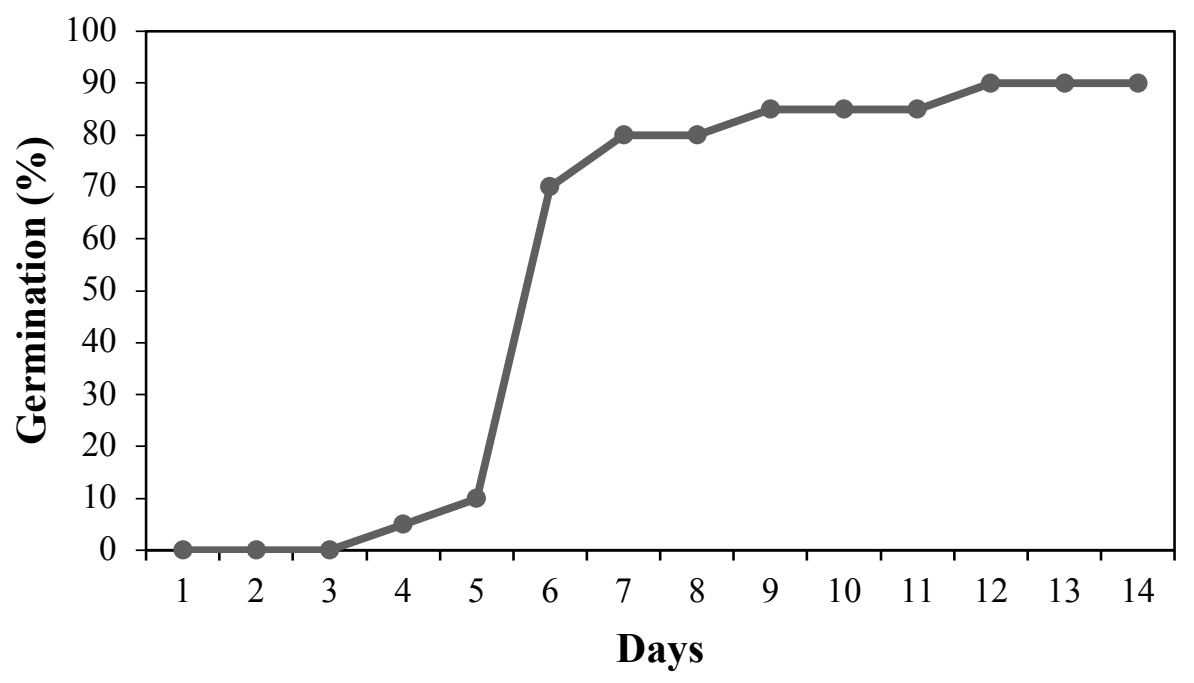

Fig. 3. Germination of Agathis labillardieri seeds during 14-day observation.

Table 2. Mean daily germination (MDG), mean germination time (MGT), germination percentage (PG), peak value (PV), and germination value (GV) of Agathis labillardieri seeds

\begin{tabular}{ccccc}
\hline $\begin{array}{c}\text { MDG } \\
\text { (N/Day) }\end{array}$ & $\begin{array}{c}\text { MGT } \\
\text { (Day) }\end{array}$ & $\begin{array}{c}\text { PG } \\
(\mathbf{\%})\end{array}$ & PV & GV \\
\hline 7.5 & 4 & 90 & 11.6 & 87 \\
\hline
\end{tabular}

\subsection{Discussion}

This study revealed that $A$. labillardieri had a relatively low number of scales containing seeds $(80.0 \pm 7.9 \%$ or containing about 106 seeds/cone $)$ and filled seeds $(50.3 \pm 5.7 \%$ or containing about 53 seeds/cone). In comparing to other Gymnospermae trees, there were reports that in Pinus albicaulis, there were 47.5 filled seeds $(59 \%)$ of 80.5 seeds per cone on average (Owens et al. 2007). In Pinus sylvestris, filled seeds varied between 21.9-66.1\% (Sivacioğlu 2010). In Pinus rzedowskii, filled seed comprised only 9.97 seeds (18\%) of 56.53 seeds per cone (Sánchez et al. 2016). It was common in conifer to have some degree of failure in seed formation and development. Relatively high in empty seeds might be due to some causes, including (1) ovule abortion; (2) the collapse and drying of the megagametophyte as a result of self-incompatibility; (3) embryo abortion and lastly (4) seed damage by insects or diseases (Owen et al. 2007). In addition, a significant low in seed production may result from a high degree of selfing, which 
commonly occurs in most conifers. High inbreeding probability in most conifers occurs due to their sexual monoecious. This occurrence may be greater in a small population than that in a large population, such as in the case of Pinus sylvestris fragmented populations of Pinus rzedowskii (Sánchez et al. 2016). The result of selfing may reduce filled seeds production significantly in conifers (Sánchez et al. 2016).

The occurrence of a high cone drop was expected in A. labillardieri. This occurrence may contribute to its low natural regeneration due to the low potency of seed formation. In monoecious conifers such as A. labillardieri, there is no apparent barrier to pollen dispersal. The female and male cone may occur in the same branch system. Therefore, there is no limitation for pollination in terms of distance since the pollen of conifers may travel as long as $600 \mathrm{~km}$ by wind (Sánchez et al. 2016). However, in the case of lodgepole pine (Pinus contorta). The cone survival appears to be related to the number of pollinated fertile ovules. The poorly pollinated cones abort, whereas well-pollinated cones retain. The well-pollinated cones produce auxins, gibberellins, and cytokinins. This product stimulates the development of the ovules and promotes the survival of the cones (Owens et al. 2005).

The formation of the embryo during the reproductive cycle in plants depends on the success of pollination. However, it seems that a high percentage of empty seed produced by A. labillardieri is not merely related to pollination. The failure of seed formation may relate to a selfing prevention mechanism. In lodgepole pine (Pinus contorta), ovule abortion occurs early after self-pollination. In contrast, a few weeks after fertilization, the abortion of the early embryo and megagametophyte occurred. In addition, in some cases of selfing, the pollen fails to germinate and form a pollen tube, or the formation of a pollen tube occurs, but its growth slows or becomes ceased. The result of this is the abortion of the ovule and the formation of small rudimentary seeds. The physiological and developmental process causing this phenomenon is not well understood (Owens et al. 2005).

Agathis labillardieri in this study was grown in the site with an elevation of 29 masl, out of the range of its natural habitat. This species most commonly occurs naturally in lowland to lower montane forests with an altitude of 200-1,700 masl (Kartika et al. 2012). The difference in elevations may be another factor that causes lower reproductive capability through the differences in ecophysiological factors that do not meet the species reproduction and regeneration (Ayari and Khouja 2013; Balekoglu et al. 2020; Keleş 2020; Lopez-Toledo et al 2017).

The findings of this study supported the statement of Rachman (2007) that the seed of this species, based on the characteristics of seed moisture content and its germination, can be categorized as a recalcitrant seed. The moisture content of the $A$. labillardieri seed collected from Klasaman was $38.9 \pm 5.7 \%$, almost similar to the seed moisture content from the plantation of Paririe Biak-Numfor of $31.8 \%$ (Rachman 2007). The moisture content is also not too different from its close relatives (Agathis dammara) of 28,8\% (Djam'an et al. 2006).

On the other hand, the germination test of $A$. labillardieri using physiologically ripe seeds showed that the first germination occurred in 4 days after sowing with the peak value (PV) achieved in 6 days after sowing with the percentage germination (PG) 90\% in the last germination test and germination value (GV) $87 \%$. The GV describes both the speed and the completeness of seed germination that determine the survival of the seedling. Therefore, the high GV means that the seeds of $A$. labillardieri had high vigor (Wani and Singh 2016).

Seeds having high moisture content and rapid germination are characteristics of the recalcitrant seeds. Seeds with these characteristics are sensitive to desiccation (Shibata et al. 2013; Walters 2015). If the moisture content of this kind of seed is lowered below the limit of its 
tolerance, then the seed will die. Seeds with this feature cannot be dried and stored for a long time. Critical seed moisture content varies between species. Below a seed moisture content of $38 \%$ was lethal for Araucaria angustifolia seeds (Shibata et al. 2013), while the critical seed moisture content of Hopea odorata was 35\%. Below that, at the moisture content of $8 \%$, no germination occurred (Nguyen et al. 2021). The critical moisture content of $A$. labillardieri seeds has not yet been known. After the seeds shedding, they could not withstand prolonged drying.

Low species regeneration, such as Olim and Nugroho (2021) and Saa et al. (2009), is not merely because of the change of reproductive capability but also due to the failure during the recruitment stage. In some cases, although the germination is successful, only a small number of the seedlings will survive and continue to grow. As the recalcitrant seed, the seeds of $A$. labillardieri will germinate immediately after cones fall, but high mortality soon after germination frequently occurs. This mortality may result from several causes. The thick litter layer and the dense of understorey vegetation beneath the stands may lead to the death of the seedlings due to the roots not being able to penetrate the A horizon of the soil (Zhao et al. 2019). Yang et al. (2014) pointed out a negative correlation between covers of shrub, herb, and litter layers to the density of the seedlings. Adilli et al. (2013) show in their study that litter biomass was the main factor influencing the density of the seedlings of Pinus pinea. Another factor related to the impact of the pest is the coral fungi that attack the newly emerging seedlings. However, the cause of the $A$. labillardieri regeneration failure has not been defined. Comparing the regeneration process and environmental factors involved in the process between natural stands and plantations of $A$. labillardieri is suggested for further study.

\section{Conclusions}

Seeds of Agathis labillardieri in Sorong Nature Park have a relatively low number of cone scales containing seeds. There were $80.0 \pm 7.9 \%$ scales containing seeds. Not all seeds produced were filled seeds, only $50.3 \pm 5.7 \%$ of the total seed were filled seed. The seeds were recalcitrant and sensitive to desiccation, characterized by high seed moisture content and a high germination rate. The moisture content and mean germination time of freshly harvested and physiologically ripe seeds were $38.9 \pm 6.3 \%$ and four days after sowing for seed to germinate, respectively. The change of reproductive capability of the species due to being planted outside its natural habitat, is not the only factor responsible for the failure of the species regeneration. Several factors as low filled seeds, seeds sensitive to prolonged desiccation, and high mortality in newly emerging seedlings, may result in low regeneration of $A$. labillardieri plantation in the Sorong Nature Park. Facilitating forest floor for immediate germination of recalcitrant seeds as in A. labillardieri is suggested to optimize its natural regeneration potential of this species.

\section{Acknowledgments}

The authors would like to express their great appreciation to Otto Tabibiati for obtaining the materials used for the study, Labuhan Sirait for taking the geographical position of the study site, and Francina F. Kesaulija for preparing the map of the study site. The authors would also like to thank Mutakhim, the technician in Silviculture Laboratory, for assisting in the study. 


\section{References}

Adili, B., Aouni, M. H. E., and Balandier, P. 2013. Unraveling the Influence of Light, Litter and Understorey Vegetation on Pinus pinea Natural Regeneration. Forestry 86: 297-304. DOI: 10.1093/forestry/cpt005

Ayari, A., and Khouja, M. L. 2014. Ecophysiological Variables Influencing Aleppo Pine Seed Cone Production: A. Review. Tree Physiology 34: 426-437. DOI: 10.1093/treephys/tpu022

Balekoglu, S., Caliskan, S., and Dirik, H. 2020. Effect of Geoclimatic Factors on the Variability in Pinus pinea Cone, Seed and Seedling Traits in Turkey Native Habitats. Ecological Processes 9(55): 1-13. DOI:10.1186/s13717-020-00264-3

BBKSDA (Balai Besar Konservasi Sumberdaya Alam) Papua Barat. 2014. Penataan Blok Taman Wisata Alam Sorong, Kota Sorong, Provinsi Papua Barat. BBKSDA Papua Barat.

Caliskan, S. 2014. Germination and seedling growth of holm oak (Quercus ilex L.): effects of provenance, temperature, and radicle pruning. iForest 7: 103-109 [online 2013-12-18] URL: http://www.sisef.it/iforest/contents/?id=ifor0967-007

Djam'an, D. F., Priadi, D., and Sudarmanowati, E. 2006. Penyimpanan Benih Damar (Agathis dammara Salisb.) dalam Nitrogen Cair. Biodiversitas 7(2):164-167.

Farjon, A. 2013. Agathis labillardieri. The IUCN Red List of Threatened Species 2013: e.T42193A2960026. DOI: 10.2305/iucn.uk.20131.rlts.t42193a2960026.en

Gonzales-Rivas, B., Tigabu, M., Castro-Marin, G., and Odèn, P. C. 2009. Seed Germination and Seedling Establishment of Neotropical Dry Forest Species in Response to Temperature and Light Conditions. Journal of Forestry Research 20(2): 99-104. DOI: 10.1007/s11676-0090018-y

Herliyana, E. N. 2012. Early Report of Red Root Rot of Ganoderma sp. on Agathis sp. (Damar) in Mount Walat Education Forest, Sukabumi, West Java. Jurnal Silvikultur Tropika 3(2): 102-107. DOI: $10.29244 /$ j-siltrop.3.2.\%25p

Kartikasari, S.N. Marshall, A. J., and Beehler, B. M. 2012. Ekologi Papua. Yayasan Pustaka Obor dan Conservation International, Jakarta.

Keleş, Ö. S. 2020. The Effect of Altitude on the Growth and Development of Trojan Fir (Abies nordmanniana subsp. equi-trojani [Asch. \& Sint. ex Boiss] Coode \& Cullen) Saplings. Cerne 26(3): 381-392. DOI: 10.1590/01047760202026032734

Lopez-Toledo, L., Heredia-Hernandez, M., Castellanos-Acuñas, D., Blanco-García, A., and SaénRomero, C. 2017. Reproductive Investment of Pinus pseudostrobus along an Altitudinal Gradient in Western Mexico: Implication of Climate Change. New Forests 48: 867-881. DOI: $10.1007 / \mathrm{s} 11056-017-9602-8$

Nguyen, T. H. H., Nguyen, T. M. H., Dang, P. D., Phung, V. K., and Kieu, T. D. 2021. Physiological Characteristics and Storage of Hopea odorata Seeds. Asian Journal of Science and Technology 12(9): 11827-11830.

Olim, M., and Nugroho, J. D. 2021. Kondisi Tegakan Tanaman Damar (Agathis labillardieri Warb) di Hutan Pendidikan Anggori, Manokwari. Seminar Nasional Silvikultur VIII. Bandar Lampung.

Owen J. N., Bennet, J., and L'Hirondelle, S. 2005. Pollination and Cone Morphology Affect Cone and Seed Production in Lodgepole Pine Seed Orchards. Canadian Journal of Forest Research 35: 383-400. DOI: 10.1139/x04-17 
Owens, J. N., Kittirat, T., and Mahalovich, M. F. 2007. Whitebark Pine (Pinus albicaulis Engelm.) Seed Production in Natural Stands. Forest Ecology and Management 255:803-809. DOI: 10.1016/j.foreco.2007.09.067

Rachman, E. 2007. Variasi Dimensi dan Kadar Air Buah Agathis (Agathis labillardieri Warb.) Berdasarkan Warna Buah. Jurnal Pemuliaan Tanaman Kehutanan 1(3): 115-121

Resmeiliana, I., Sofyan, K., and Achmadi, S. S. 2014. Karakteristik Asam Resin Kopal Agathis loranthifolia Sukabumi. Jurnal Sains Terapan 4(2): 13-17.

Saa, A., Rettob, B. B., and Murjoko, A. 2009. Permudaan damar (Agathis labillardieri Warb.) di Kawasan Teminabuan Kabupaten Sorong Selatan. Beccariana 11(1): 1-11.

Sánchez, P. C., Valerio, P. D., Sáenz-Romero, C., and Diego, Y. H. 2016. Reproductive Success and Inbreeding Differ in Fragmented Populations of Pinus rzedowskii and Pinus ayacahuite Var. Veitchii, Two Endemic Mexican Pines Under Threat. Forests 7 (178): 1-17. DOI: 10.3390/f7080178

Shibata, M., Coelho, C. M. M., and Steiner, N. 2013. Physiological Quality of Araucaria angustifolia Seeds at Different Stages of Development. Seed Science and Technology 41: 214-224. DOI: 10.15258/sst.2013.41.2.04

Siburian, R. H. S., Trirbo, M., and Anggrianto, R. 2020. Growing Site Characteristics of Agathis labillardieri Warb in the Natural Forests of Siwi Momiwaren, West Papua. Jurnal Sylva Lestari 8(3): 297-307. DOI: 10.23960/js138297-307

Sivacioğlu A. 2010. Genetic Variation in Seed and Cone Characteristics in Clonal Seed Orchard of Scots Pine (Pinus sylvestris L.) Grown in Kastamonu-Turkey. Romanian Biotechnological Letters 15(6): 5695-5701.

Walter, C. 2015. Orthodoxy, Recalcitrance and in Between: Describing Variation in Seed Storage Characteristics using Threshold Responses to Water Loss. Planta 242(2): 397-406. DOI:10.1007/s00425-015-2312-6

Wani, M. R., and Singh, S. S. 2016. Correlation Dynamics of Germination Value, Germination Energy Index and Germination Speed of Pongamia pinnata (L,) Pierre Seed of Pendra Provenance, Chhattisgarh, India. International Journal of Research in Agriculture and Forestry 3(4):28-32.

Wulandari, W., Bintoro, A., and Duryat, D. 2015. The Effect of Seed Size on Seed Germination of Mirabow (Intsia palembanica). Jurnal Sylva Lestari 3(2): 78-88. DOI: 10.23960/js1237988

Yang, X., Yan, D., and Liu, C. 2014. Natural Regeneration of Trees in Three Type of Afforested Stands in the Taihang Mountains, China. PLos ONE 9(9): e108744. DOI:10.1371/journal.pone.0108744

Zhao, C., Cai, Y., Huang, X., Liu, Q., Zhu, C., Yu, J., Wang, Z., and Liu, B. 2019. Effects of Chinese Fir Litter Cover on Its Seedling Emergence. and Early Growth. Chinese Journal of Applied Ecology 30(2): 481-488. DOI: 10.13287/j.1001-9332.201902.023 